\title{
Potential of biomass residues from oil palm agroindustry in Indonesia
}

\author{
Dwi Ermawati Rahayu ${ }^{1,2 *}$, Dutarama Nasarani ${ }^{3}$, Wahyono $\mathrm{Hadi}^{2}$, and Budisantoso Wrjodirjo ${ }^{3}$ \\ ${ }^{1}$ Mulawarman University, Environmental Engineeringg, 75123 Samarinda, Indonesia \\ ${ }^{2}$ Institut Teknologi Sepuluh Nopember, Environmental Engineering, 91944 Surabaya, Indonesia \\ ${ }^{3}$ Institut Teknologi Sepuluh Nopember, Industry Engineering, 91944 Surabaya, Indonesia
}

\begin{abstract}
Oil Palm agroindustry is growing rapidly in Southeast Asia especially Indonesia and Malaysia. Based on GAPKI data, Indonesia's CPO production 2017 is 38.17 million tons and PKO of 3.05 million tons. Production activities in palm oil agro-industry in addition to producing PKO and CPOl produce solid waste from the plantation and palm oil mill, Palm Oil Mill Effluent (POME) from the palm oil mill. The biomass waste of oil palm agro-industry comes from activities in plantations in the form of midrib, leaves and palm tree trunks. While from the palm oil mill produced solid waste in the form of palm kernel shells (PKS), mesocarp fibers (MF) and empty fruit bunches (EFB). The waste is classified as biomass residue that can be utilized so that it has added value. Biomass potential in Indonesia can be estimated from the productivity of oil palm. The volume of biomass is 5,5-8\%, empty bunches $20-23 \%$, palm fronds $13.5-15 \%$, $15 \%$ palm fiber from 1 ton of fresh fruit bunches. The total potential of oil palm solid waste biomass in Indonesia 2017 is 20.07 million tons and POME is 23.7 million tons. The largest distribution of biomass is in Riau, North Sumatra, South Sumatra province.
\end{abstract}

\section{Introduction}

Oil Palm agroindustry is growing rapidly in Southeast Asia especially Indonesia and Malaysia. The oil palm plantations in Indonesia consists of smallholdings, government estate plantations and private estate plantations. The total of plantation area has increased significantly from 8.4 million hectares in 2010 to 11.26 million hectares in 2015 and is estimated to be 12.31 million hectares in 2017. Based on GAPKI data, Indonesia's CPO production 2017 is 38.17 million tons and PKO of 3.05 Million tons. It makes Indonesia the world's largest producer of palm oil. [1]

Production activities in palm oil agro-industry in addition to producing $\mathrm{PKO}$ and $\mathrm{CPO}$ produce solid waste from the plantation and palm oil mill, Palm Oil Mill Effluent (POME) from the palm oil mill. The biomass waste of oil palm agro-industry comes from activities in plantations in the form of midrib, leaves and palm tree trunks. While from the palm oil mill produced solid waste in the form of palm kernel shells (PKS), mesocarp fibers (MF) and empty fruit bunches (EFB) [2], [3], [4], [5], [6]

United Nations Framework Convention on Climate Change (UNFCCC, 2005) defined biomass is non fossil and biodegradable organic material originating from plant, animals and microorganism. This shall also include products, by product, residues and waste from agriculture, forestry and related industries as well as the non fossilized and biodegradable organic fractions of industrial and municipal waste [7]. Refer to the definition, the waste is classified as biomass residue that can be utilized.

Though biomass waste can contribute the greatest potential for supply of renewable and sustainable energy sources with abundant quantities. Because biomass is the fourth largest source of energy after coal, petroleum and natural gas. In 2010, in Sweden $14 \%$ of the energy comes from biomass, in Finland 21\% of its total energy consumption comes from the forestry sector and the United States produces 9 million watt electricity from biomass. While in Germany, biomass contributes about $68.9 \%$ of the total energy as renewable energy. In Indonesia, the potential source of biomass waste from oil palm agro-industry is very large based on the existing oil palm plantation area

So it is necessary to research to determine the quantity of biomass potency of solid waste from oil palm agroindustry. The purpose of this research is to give the overview regarding the availability and distribution of the oil palm biomass wastes and potential for utilization.

\footnotetext{
* Corresponding author: dwiermarahayu $@$ ft.unmul.ac.id
} 


\section{Materials and methods}

\subsection{Data collection}

Data were collection through The Official publication such as Tree Crop Estate Statistics of Indonesia 2015-
2017 Palm Oil [1] 2016 Handbook of Energy \& Economic Statistics of Indonesia Final Edition [8].

\subsection{Data analysis and calculation}

Each biomass was calculated as follows :

Table 1. Calculation of Biomass.

\begin{tabular}{|c|c|c|c|c|c|c|c|}
\hline \multirow{2}{*}{$\begin{array}{l}\text { Residues Sources } \\
\text { FFB }\end{array}$} & \multirow{2}{*}{$\begin{array}{l}\text { Type Residues } \\
\text { PKS } \\
\end{array}$} & \multicolumn{6}{|c|}{ \% weight } \\
\hline & & 5,50 & 5,50 & 7 & $5-7$ & $5,5-7$ & $5-7$ \\
\hline & EFB & 22,00 & 22,00 & 23 & $20-23$ & $22-23$ & $20-23$ \\
\hline & Mesocarp Fiber & 13,50 & 13,50 & & $11-12$ & $13.5-15$ & $11-15$ \\
\hline \multirow{4}{*}{$\begin{array}{l}\text { Oil Palm (froam } \\
\text { pemanenan) }\end{array}$} & OPT & 70,00 & 74,50 & 50 & 65 ton/ha & 75 ton/ha & $65-75$ ton/ha \\
\hline & OPF & 20,50 & 14,5 & 20 & & 15 ton/ha & $14,5-20,5$ \\
\hline & Leaf & 6,53 & & & & & \\
\hline & Etc & 2,97 & & & & & \\
\hline \multirow[t]{2}{*}{ POME } & & & & 67 & $50-60$ & & \\
\hline & & [2] & [3] & [4] & [5] & [6] & This paper \\
\hline
\end{tabular}

\section{Results and discussion}

\subsection{History of palm oil crop in Indonesia}

Palm oil was imported to Indonesia by the Dutch East Indies government in 1848 from West Africa which was then planted in the Bogor Botanical Garden. When there was an increase in the demand for vegetable oils due to the industrial revolution in the mid-19th century, then came the idea of making oil palm plantations. In 1911, palm oil began to be cultivated and cultivated commercially with its pioneer in the Dutch East Indies

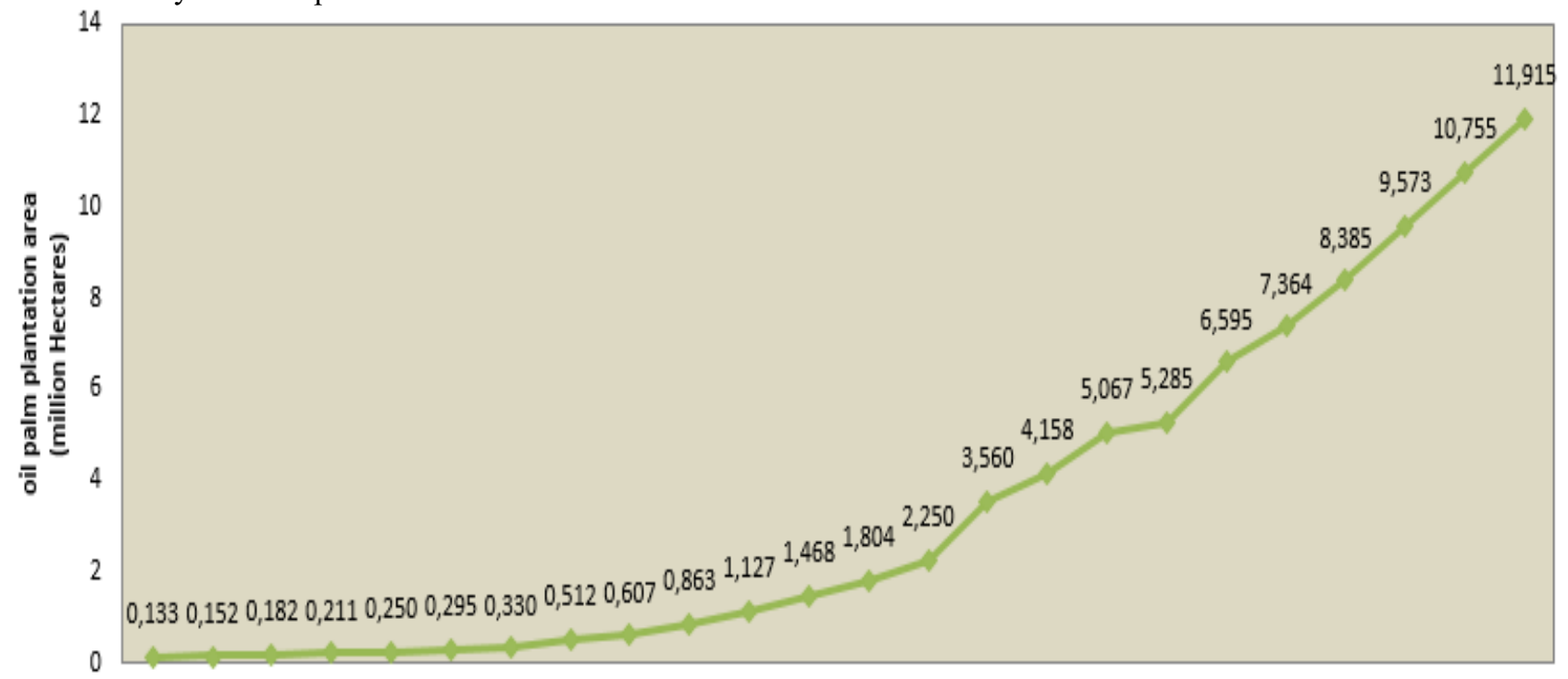

197019721974197619781980198219841986198819901992199419961998200020022004200620082010201220142016 year

Fig. 1. Statistics on oil palm crops in Indonesia.

\subsection{Distribution of palm oil crop in Indonesia}

Indonesian oil production mainly come from six provinces contributed as much as $73.69 \%$ of the total palm oil production in Indonesia. The first and second ranks are Riau and North Sumatra provinces with a
Adrien Hallet followed by K. Schadt. The first palm oil plantations are located on the East Coast of Sumatra (Deli) and Aceh covering an area of 5,123 hectares which later increased to 32,000 $\mathrm{Ha}$ in 1925 and 3,400 ha in Malaysia. But in West Africa alone large-scale oil palm planting began in 1910. [9].

Statistics on oil palm crops shows that in 1970s, indonesia had only 133,298 ha of oil palm plantation. Since then, the oil palm crops area are has increased significantly as shown in fig 1 . In 2017 , oil palm crops area estimated 11,312 million hectares 


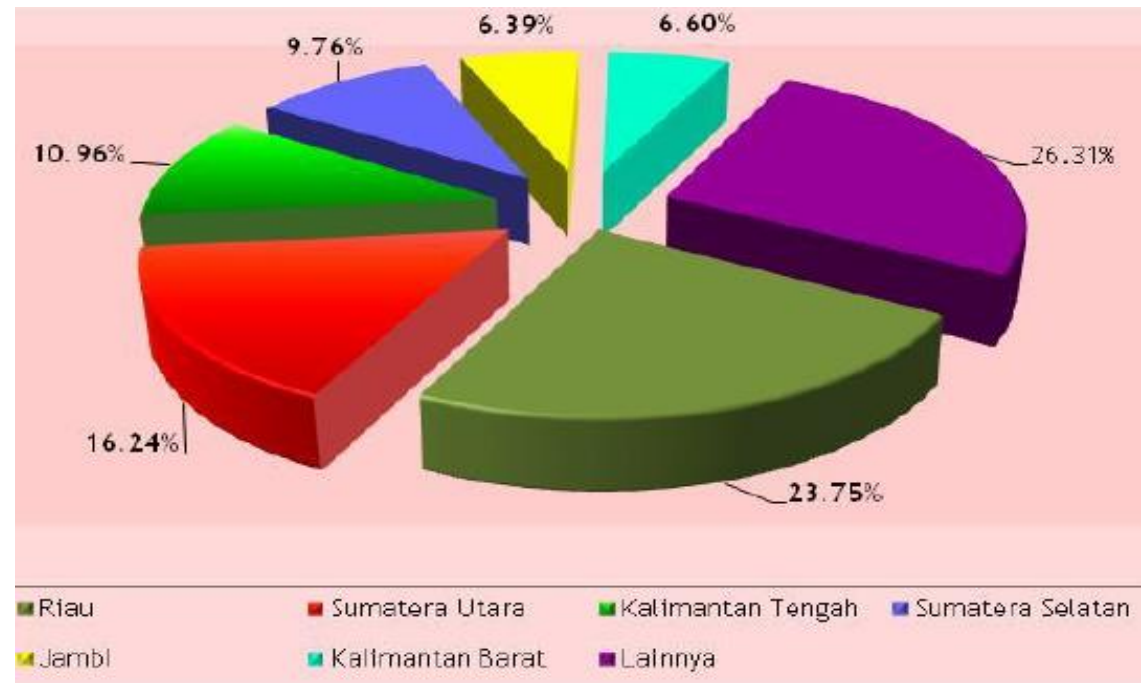

Fig. 2. Distribution of palm oil crop in Indonesia.

\subsection{Availability biomass from oil palm agroindustry}

In addition to producing palm oil and palm kernel oil, waste is also produced as a waste of biomass with a large percentage of components. Biomass derived from the plantation area in the form of leprosy is generated when the harvesting process coincides with the collection of
TBS as well as the maintenance of each routine. While the palm tree trunks are produced at the time of replanting plants that have decreased productivity that is at the age of 25-30 years [2]. While PKS is produced by solid waste with the largest percentage of empty bunches of $20-23 \%$ of processed FFB [2], [3], [4],[5], [6] as shown in Fig. 3.

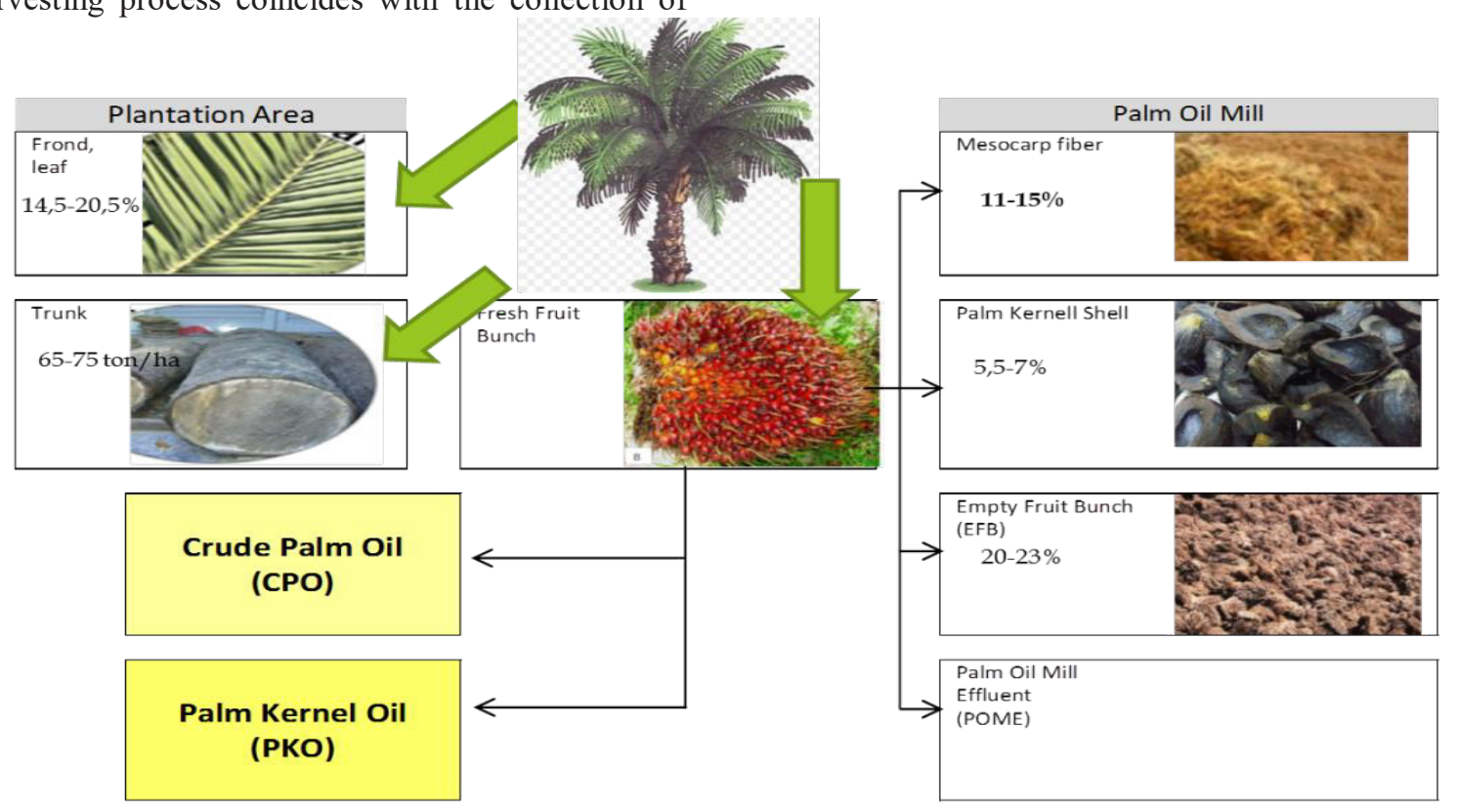

Fig. 3. PKS is produced by solid waste with the largest percentage of empty bunches of $20-23 \%$ of processed FFB.

Biomass estimates generated from oil palm agroindustry can be calculated based on these data and publications related to Indonesian oil palm statistics that contain the extent and productivity of plantation land in Indonesia. The largest oil palm solid waste biomass is in the form of empty bunches with an estimated total of more than 40 million tonnes followed by waste in the form of trunks of palm trees and midribs with volumes of more than 30 million tons. The total potential of solid waste biomass generated by oil palm plantations in Indonesia is more than 100 million tons of biomass material (Fig. 4). Biomass estimation data generated per province shows the same condition. The distribution of biomass volume is uneven because in some provinces such as Central Java, East Java, DKI, DIY, Bali, NTT, NTB, North Maluku there is no area of oil palm plantation. The amount of biomass waste is very abundant is largely not utilized to the fullest.

\footnotetext{
* Corresponding author: dwiermarahayu@fft.unmul.ac.id
} 


\begin{tabular}{|c|c|c|c|c|c|}
\hline Uraian & Satuan & 2014 & 2015 & 2016 & 2017 \\
\hline Luas Area Perkebunan & $\mathrm{Ha}$ & $10,754,801$ & $11,260,277$ & $11,914,499$ & $12,307,677$ \\
\hline Produksi & Ton & $182,724,069$ & $191,312,106$ & $202,427,338$ & $209,107,432$ \\
\hline Produktivitas & $\mathrm{kg} / \mathrm{Ha}$ & 3,645 & 3,625 & 3,763 & 3,817 \\
\hline \multicolumn{6}{|c|}{ Biomassa padat } \\
\hline PKS Biomas s maks & Ton & $12,790,685$ & $13,391,847$ & $14,169,914$ & $14,637,520$ \\
\hline PKS Biomass minimum & Ton & $9,136,203$ & $9,565,605$ & $10,121,367$ & $10,455,372$ \\
\hline PKS Biomas s a rata rata & Ton & $10,963,444$ & $11,478,726$ & $12,145,640$ & $12,546,446$ \\
\hline EFB Biomas s a maks & Ton & $42,026,536$ & $44,001,784$ & $46,558,288$ & $48,094,709$ \\
\hline EFB Biomas sa minimum & Ton & $36,544,814$ & $38,262,421$ & $40,485,468$ & $41,821,486$ \\
\hline EFB Biomass Rata Rata & Ton & $39,285,675$ & $41,132,103$ & $43,521,878$ & $44,958,098$ \\
\hline Mesocarp Biomass maks & Ton & $24,667,749$ & $25,827,134$ & $27,327,691$ & $28,229,503$ \\
\hline Mesocarp Biomass minimum & Ton & $20,099,648$ & $21,044,332$ & $22,267,007$ & $23,001,818$ \\
\hline $\begin{array}{l}\text { Mesocarp Biomassa Rata } \\
\text { Rata }\end{array}$ & Ton & $22,383,698$ & $23,435,733$ & $24,797,349$ & $25,615,660$ \\
\hline biomass OPT min & Ton & $34,953,103$ & $36,595,900$ & $38,722,122$ & $39,999,950$ \\
\hline Biomass OPT maks & Ton & $40,330,504$ & $42,226,039$ & $44,679,371$ & $46,153,789$ \\
\hline OPT Rata Rata & Ton & $37,641,803.50$ & $39,410,969.50$ & $41,700,746.50$ & $43,076,869.50$ \\
\hline OPF Biomas s a maks & Ton & $37,458,434$ & $39,218,982$ & $41,497,604$ & $42,867,024$ \\
\hline OPF Biomass minimum & Ton & $26,494,990$ & $27,740,255$ & $29,351,964$ & $30,320,578$ \\
\hline OPF Biomas s a Rata Rata & Ton & $31,976,712$ & $33,479,619$ & $35,424,784$ & $36,593,801$ \\
\hline Total Maks Biomassa Padat & Ton & $151,896,507$ & $159,035,648$ & $168,275,618$ & $173,828,707$ \\
\hline Total Mins Biomassa Padat & Ton & $132,606,159$ & $96,612,614$ & $102,225,806$ & $105,599,253$ \\
\hline $\begin{array}{l}\text { Total Rata-rata Biomassa } \\
\text { Padat }\end{array}$ & Ton & $142,251,333$ & $109,526,181$ & $115,889,651$ & $119,714,005$ \\
\hline
\end{tabular}

Fig. 4. The total potential of solid waste biomass generated by oil palm plantations in Indonesia.

\subsection{Current utilization}

The biomass waste is conventionally used directly as a boiler fuel in the palm oil industry without a prior conversion process [6]. Section of waste of oil palm biomass which is exploited is shell and fiber fiber which have high calorific value as fuel for steam at industry and electricity. But the need for this industry is much lower than that of the existing biomass sources. So it continues to increase in number each year [10]. Meanwhile, empty fruit bunches that are material with high water content are stacked away in the palm oil industry area because transportation and disposal costs are expensive and ineffective. The combustion activity of fiber for boiler fuel and empty bunch disposal contributes to the negative impact on the environment [11].

\section{Conclusion}

Biomass from Oil Palm agroindustry is very abundance (more than 100 million ton of biomass). Its potential to convert become added value product.

\section{References}

1. D.J. Perkebunan, Statistik Perkebunan Indonesia 2015-2017 Kelapa Sawit (Sekretariat Direktorat Jendral Perkebunan, Direktorat Jendral Perkebunan, Kementrian Pertanian, 2016)

2. F. Abnisa, A. Arami-niya, W. M. A. W. Daud, J.N. Sahu, I.M. Noor, Utilization of oil palm tree residues to produce bio-oil and bio-char via pyrolysis, Energy Convers. Manag. 76 1073-1082. (2013)
3. M. Azri, F. Abnisa, W. Mohd, A. Wan, N. Abu, A review of torrefaction of oil palm solid wastes for biofuel production, Energy Convers. Manag. 149 101-120. (2017)

4. K. Suzuki, N. Tsuji, Y. Shirai, M. Ali, Biomass and Bioenergy Evaluation of biomass energy potential towards achieving sustainability in biomass energy utilization in Sabah, Malaysia, Biomass and Bioenergy. 97 149-154. (2017)

5. A. Tajalli, Panduan Penilaian Potensi Biomassa Sebagai Sumber Energi Alternatif di Indonesia, 1st ed., Penabulu alliance, (2015)

6. S.-H. Kong, S.-K. Loh, R.T. Bachmann, S.A. Rahim, J. Salimon, Biochar from oil palm biomass: A review of its potential and challenges, Renew. Sustain. Energy Rev. 39 729-739. (2014)

7. P. Basu, Biomass Gasification and Pyrolysis, oion ligno, (2010)

8. anonymous, 2016 Handbook of Energy \& Economic Statistics of Indonesia Final Edition, (Ministry of energy and Mineral Resource Republic of Indonesia, Jakarta, 2005)

9. R.H. V Corley, P.B. Tinker, The Oil Palm, Fifth edit, (Wiley Blackwell, 2016)

10. U. Elmer, I. Nygaard, Sustainable energy transitions in emerging economies: The formation of a palm oil biomass waste-to-energy niche in Malaysia 1990 - 2011, Energy Policy. 66 666-676. (2014)

11. K. Saswattecha, C. Kroeze, W. Jawjit, L. Hein, Assessing the environmental impact of palm oil produced in Thailand, J. Clean. Prod. 100 150-169. (2015)

\footnotetext{
* Corresponding author: dwiermarahayu@fft.unmul.ac.id
} 